Tarih Kültür ve Sanat Araştırmaları Dergisi

Revue des Recherches en Histoire Culture et Art مجلة البحوث التاريخية والثقافية و الفنية
Vol. 7, No. 4, November 2018

Copyright (c) Karabuk University http://kutaksam.karabuk.edu.tr

\title{
DOI: 10.7596/taksad.v7i4.1817
}

Citation: Burtseva, Z. (2018). Geopoetics of the North: The Literature of the Indigenous Peoples of the North of Yakutia. Journal of History Culture and Art Research, 7(4), 75-84. doi:http://dx.doi.org/10.7596/taksad.v7i4.1817

\section{Geopoetics of the North: The Literature of the Indigenous Peoples of the North of Yakutia}

\author{
Zhanna Valer'evna Burtseva ${ }^{1}$
}

\begin{abstract}
In the literature of the Indigenous Peoples of the North of Yakutia, the conceptual role is played by the image of the North, which is advisable to consider in the mainstream of geopoetics or poetics of space, revealing the regional picture of the world and the cultural landscape. In a general sense, geopoetics is thought of as a mental, intellectual, and artistic development of geographical space by man. In the study, we focus on the fact that the North in the literature of Yakutia is a cultural mental category, a unique space, in the aspect of the presence of real spatial components and those imaginative mythopoetic connotations that this space is endowed with. In this regard, the unique natural parameters of the North, its cultural and historical specificity, give reason to assert, first of all, the existence of the Northern text of Yakutia's literature, a special semiotic space, and second of all, the Northern text is more a phenomenon not thematic, but mental, because it reflects a special version of the ethnic picture of the world.

The study of this regional Northern text will allow us to outline the broad possibilities of comparative historical and typological research. The Northern text in the literature of Yakutia became the most representative in the second half of the 20th century, it is caused and formed by literary and extra-literary factors, is revealed in all semiotic systems. Its semantic core is the literature of small-numbered peoples of the North on the basis of characteristic themes, key images-concepts and symbolic motives. Literature of the indigenous peoples of the North of Yakutia includes literature of Yukaghir, Evens, Evenks people, which have different cultural and philosophical, historical and genetic roots, but also have territorial, contact-typological, ethnic unity.
\end{abstract}

Semiotic space in literary texts representing the North, is represented mainly in the generalized historicalphilosophical and natural-philosophical character, landscape-geographical and mythological uniqueness of the Northern region.

Keywords: North, Northern text, Regional text, Geopoetics, Literature of the indigenous peoples of the North, Literature of Yakutia, Text, Space, Cultural landscape, Topos.

\footnotetext{
${ }^{1}$ Candidate of Philological Sciences, Senior Scientific Researcher of Institute for Humanities Research and Indigenous Studies of the North RAS SB, Yakutsk, Russia. E-mail: gvburtseva@mail.ru
} 


\section{Introduction}

The concept of "North" includes such definitions as the Russian north, polar, european, extreme, boundless, arctic, and circumpolar. And all these terms do not have clear definitions, even in terms of geographical boundaries. The concept of "North" is a more historical and cultural concept than geographical or administrative or geopolitical. Moreover, the North forms additional meanings associated with its mythological cultural metaphor.

If we talk about the Northern text of Russian literature, it is inextricably connected with linguistic and cultural concept of "Russian North", which, according to E.Sh. Galimova, is the "mystery of Russian life, Russian history, Russian culture, Russian spirituality and soul of Russia, and also the mystery of the Russian word" (Galimova, 2018, p.15). This toponym commonly used for a vast territory covering the Northern areas of Russian settlement in the European part of Russia: Arkhangelsk, Vologda, Murmansk regions, the South-Eastern part of the Republic of Karelia, the South-Western part of the Republic of Komi, as well as part of the adjacent North territories of the Kirov, Kostroma, Yaroslavl, Tver, Novgorod and Leningrad regions.

The uniqueness of the North as a special model of world order and philosophy lies in its categorical incompatibility neither with urban culture, nor with Western or Eastern civilizations. The researchers identify the single concept of "Northern philosophy" as a way of being in the world civilization (Popkov \& Tyugashev, 2006), as well as the specific ethnophilosophy of indigenous peoples of the North.

In Yakut culture, the North is denoted by the general term "qotu", and the inhabitants of the Northern territories call themselves "qotularbyt" (northerners). In daily life often use the term "tungus" regarding the Evenks and the Evens. However, the Evens are "lamuts", from the Tungus word "lamu" - "sea", because they inhabit the Northern part of the Okhotsk coast and the North-Eastern regions of Yakutia, while the Evenks live in the rest of Eastern Siberia. In ethno-cultural terms the Evenks also have differences. In written sources mentioned "unmounted" (hunters), "vagrant" and "nomadic" (reindeerbreeder) tunguses. The Evenks, like the taiga people, are also great hunters, and the Evens, the tundra people, have been engaged in reindeer husbandry since ancient times. Yukaghirs call themselves "odul" ("odul/vadul" - "strong"), one of the most ancient peoples, live in the Northern regions of Yakutia, in the Magadan oblast and Chukotka okrug.

The concept of sustainable development of indigenous peoples of the North, Siberia and the Far East of the Russian Federation emphasizes the priority importance of preserving their native habitat and lifestyle, economic activities in their places of traditional residence. The ancient Northern ethnic groups not only are not exposed to the so-called "re-education" or inclusion in the "modern civilization", but, on the contrary, need to ensure that the conditions of their existence as consistent with their traditions. By confession of one of the Evens writer A. Krivoshapkin "from the very beginning civilization brought a great harm to a measured rhythm of life of the Northern ethnic groups. These are birthmarks of civilization drunkenness, alcoholism, social diseases, unemployment, the threat of the complete disappearance of the native language and original traditional culture" (Krivoshapkin, 1986, p.5).

The main character of these peoples is a nomad-reindeer herder or taiga hunter, embodying the concept of "one world" of man and nature, which becomes a universal way of depicting life in literature. At the same time, the nomadic Northern peoples are very different from the nomadic steppe peoples, even because the Northern nomads adapt to such conditions that seem simply unbearable for human life. The North is not just a habitat, but a harsh place for the test and survival of the chosen people, with its own rules and laws. Nature here requires a person not just a sense of unity with it, but also a deep connection with every particle of the world, which is the basis for understanding the essence of Northern literature. 
Despite the global transformation of ethnic self-identity in the modern world, the widespread process of transculturation, in the Northern literature, the ability of the ethnic group to represent its archaic and traditional culture as a great advantage remains the most. The concept of individuality and autobiography is one of the central elements of the entire Northern literature of Yakutia. An example of this is poetic and prosaic works, in particular, the autobiographical novel-trilogy of Even writer A. Krivoshapkin "Life-long nomad" (2000), "Beneath the shadow of the North star" (2014) and "My Life, I would choose you again!" (2015), an autobiographical narrative by Even writer N. Tarabukin "My childhood" (1936), essay of the Yukaghir literature founder Teki Odulok "On the far North" (1927), memoirs of Yukaghir writer N. Kurilov "Lurking sense of destination" (2013), the stories of Evenk writer G. Keptuke "Having his own name Djheltula river" (1988), "My father is Santa Claus" (2010) and many others.

\section{Methodology}

The study of the Northern text is based on the basic methods of studying urban texts, which are based on the conceptual semiotic and cultural principles of analysis (Toporov, 2003; Lotman, 1992, etc.). The understanding of the local "supertext" phenomenon began in St. Petersburg and today, along with the "urban" texts, "regional" texts are actively studied. Since the regional text contains different cultural codes than space of city, and generally differs in a number of specific properties, the methodology developed by the urban texts researchers, while remaining basic, cannot be sufficient in understanding the phenomenon of the regional text. The very concept of the Northern text in relation to the literature of Yakutia requires new theoretical and methodological studies, taking into account geographical, cultural, historical, ethnographic, social and mythological features of the region.

The most productive method of studying the North as a text is an integrated approach. In this regard, the subject of the geopoetic discourse analysis is the image of place and the foundations of regional identity, taking into account the peculiarities of geographical realities. In this regard, the artistic picture of the world includes a set of landscape characteristics, images, space, time, and movement.

In the 1970s, in France, the word "geopoetics" was introduced into use by the poet and essayist of Scottish origin Kenneth White, returning to a holistic spatial perception and experience of the world. Today, thanks to the works of poet Igor Sid, writer Yuri Andrukhovich, philologists Vladimir Abashev, Elena Galimova and others, the term has become a specific section of poetics.

The cultural landscape is interpreted as a sign system, when the "place" affects its inhabitants mainly due to the signs-symbols of this territory. V.N. Toporov notes that "through the world of things and through man, space is assembled as a hierarchical structure of meanings subordinated to the whole" (Toporov, 1983, p.242).

\section{Discussion}

The components of the Northern landscape are images of tundra: distant, eternal taiga, frozen sea, high wooded mountains, forest over a steep bank (Even lang. - dyapkanga), vertices of Dzhugdzhur, rocks (Even lang. - kadary), fabric canopies (Even lang. - elbuce), mountain rivers, swamps, ice cold rivers of the taiga, the nomadic paths, thickets of willow (Even lang. - hyatakagi), poplar groves, glades, edges of the earth of Anabar, Sebyan, snowy rocks of Albay, river Nyavaÿnadanu (Yukaghir lang. - the river of the White Wolf), river Labunmedenu (Yukaghir name of the Bolshaya Chukochya river), river Nungeden (Yukaghir name of the river Nelemnoe) and many others.

As expressed by Chudnova et el., "language and mentality are interrelated because the language reflects those features of the extra linguistic reality, which appear to be relevant to people who use the language, 
and mastering the language, the native speaker begins to see the world from the perspective, suggested by his native language and gets used to the conceptualization of the world, common for this culture. In this sense, all the words that verbalize language-specific concepts simultaneously "reflect" and "shape" the mentality and cultural space of native speakers" (2018, p.365). Characteristic of the Northern space has the property of marginality, there is always present the images of the dichotomy, geopoetics semantic of boundary, border. If we talk about the Yakut literary tradition, in the early 20th century, the Northern theme is directly related to winter, also contains the traditional archaic paradigm "winter - death", motives-antinomy summer - winter, good - evil, beautiful - ugly, joy - sadness, light - darkness. Winter is identified with darkness, hunger, punishment, longing, exile, madness, but over time in the second half of the 20th century, the aesthetic assessment of winter undergoes significant metamorphoses. In general, lyrical image of the Yakut winter, taken as a holistic art education, is characterized by ambivalence, opposite semantic meanings. On the one hand, the Yakut national picture of the world is characterized by the perception of winter as a raging destructive element, on the other hand, as a metaphor of eternity, peace, purity, embodied mainly in the concept of snow.

The North or the Arctic in the Northern literature of Yakutia, usually is associated most often with the periphery, the edge of the earth, the deaf margin, which is expressed in the works of art in the structuring of space on the principle of binary oppositions, such as, North/civilization, nature/civilization, own/of someone else, nomadic as the opposition of settled life, life/death, severe/fragile, freedom/unfreedom, good/evil, citizens/northerners, past/present, archetypal images of the threshold, the border.

The idea of the North as a place of testing soul and body for endurance, courage, honesty and reliability is connected with the geographical position of the North on the edge of the earth, where everything is on the verge of human capabilities. Geopolitically, the North is an Arctic zone of permafrost, with the vast majority of Northern lands being tundra, sometimes impassable taiga. Natural and climatic conditions of the Northern territories suggest discrete human settlement, scattered on a fairly homogeneous relief space. The North tests people for endurance, courage, strength, reliability, fortitude, purity of soul and thoughts.

And if tested by our North,

He will not bend at any feature,

He is the man for sure -

He will save you from any trouble.

("I will not say: "I will go with him to intelligence")

(Krivoshapkin, 2016, p.30).

At the same time, the North requires both a severe struggle for survival, an everyday battle with the forces of nature, and a harmonious model of being, a deep unity with every particle of the surrounding world.

These relatives also,

like tundra, are open.

Affectionate hearted

and generous by an innocent soul.

In distant lands

such impulses are forgotten, 
And only here

they always roam with me.

("Monologue of the tundra-dweller") (Krivoshapkin, 2016, p.13).

The main in the Northern literature is the natural sphere, so all the elements of the raging geopoetics of the North raising up against the background of a large-scale arena of violence of the forces of nature. The image of the Northern land is modeled by contrasting spatial characteristics of its fabulous beauty and harsh truth, where a struggle of human for survival has been longed for centuries, his ability to become part of the natural world.

Tested by frost and snow,

Son of the North on the pedestal soared.

He raised us to the seventh heaven,

He overcame all the strongest in fights.

("Son of the North") (Krivoshapkin, 2016, p.47).

Nomadic life every day demanded strength of spirit and willpower, formed a special character traits. The reindeer breeder must fight not only for his own survival, but also for his deer, which are also in constant danger. In the winter they are killed by the severe frost, in late spring from the black water with a strong current, in the summer of voracious mosquitoes and the diseases caused by the drought.

As a rule, the authors describe the marginal character of the Northern space, the combination of opposite features, motives and images with the semantics of transition. Northern nature as a capricious woman, often changing its appearance: the fierce frost, the unbearable heat, the torrential rains, the absolute silence, when no breeze, the sky is a bottomless dome of the blue, the snowfall and the terrible wind or the evil blizzard.

One of the main features is the metaphorical-anthropomorphic personification in the creation of the mythopoetic image of the natural world of the North, when the whole world as a single living organism. Thus, in the poetry of A. Krivoshapkin the description of the North implemented by following metaphors: "land of congeners", "shining expanse", "the Arctic's fragile gem", "life, special, own", "distant tundra", "white raw-hide tent", "generous Northern land", "great white", "cold as awards", "white tenderness", "original snow", "Aurora Borealis light" and others. Lyrics of Yukaghir man G. Kurilov - Uluro-Ado also abounds in the description of the North as "an Oecumenical miracle" in which "sweet creak of the snow"," the night sky flows silver", "a gentle line of an ancient song", "ancestors who became the body of the tundra", "wings of the spirit", "endless celebration"," dancing Siberian crane", "a song of pure love" and other living metaphors in a special sense of spiritual idyll and nostalgia for the past time and the people who lived in it.

From the organization point of view, the Northern space is distinguished by simultaneous characteristics in horizontal and vertical dimensions. The North gives the ability to feel the proximity of the horizontal and vertical dimensions of space when the sky and the earth merge. The tundra's vast expanses - one of the topos, which does not have the boundaries between heaven and earth, between day and night at the time of white nights. Crossing the space-time boundaries by the hero can be considered as a philosophical phenomenon, as the nomad overcomes not only the geographical boundaries, fixing the change of landscape sketches, but also the boundaries through the centuries. They turn it to eternity in some sense, free from the time when the metaphorical image of the historical past and future generations meet at the 
one point. The temporal boundaries between the past and the present in the North are erased and even cease to exist. In this sense, the North appears to be the spatial timeless equivalent of eternity.

In the spatial model, the North is endowed with the function of distinguishing "own" and "another's" worlds. Achetypical mythologies "own-another's" as part of the chronotopic structure of the myth are the basis of the ideas organization about the North. This opposition is implemented in contradistinction of the North (Arctic) image to civilization, the city and in contradistinction of the Northern "deer" people to citizens. The images of "others", "outsider" embodied in the metaphors "the influx of avaricious tribes", "children of prophet", "other tribe", from which "crying day and night the native land". "Outsider" is not even able to see life in the vast snowy expanses of the tundra.

To an outsider, as if he were blind

The whole Arctic is dumb and empty.

In his eyes there is only white snow

Lies as an endless desert.

("Face of the Arctic") (Krivoshapkin, 2016, p.11).

The marginality of the Northern space character also lies in the description of the boundary lines, such as the opposition of the past and the present, and this is due to the invasion of civilization to the natural life of the "ancient tribes". In this regard, the North becomes the border between the vicious world of people and the pristine beauty of nature.

Glowed the fires of the nomadic,

Like rare stars in the dark,

Had been born and had been living alives,

And the dead slept in the ground.

... In harmony with the eternal taiga,

The ancient people had stayed...

And rushed the other tribe

To the glitter of the Golden calf

Forgot of peace the forests,

The animals were hammered by lead.

("Thoughts at Dzhugdzhur") (Krivoshapkin, 2016, p.34).

Culture is always connected with the past, with collective memory, so the concept of memory in literature coexists with a keen sense of duty to preserve the previous spiritual experience, the continuity of the moral life of people. In most of the works A. Krivoshapkin directly says that the once "clean, generous North region" became the patrimony of mass poaching, outright robbery and "a relative, who lost his track as an outcast, on his own land". G. Kurilov - Uluro Ado also admits: "and my people began to die out, - immensely honest, - have lived on permafrost as much as ten thousand years" (Kurilov, 2013, p.34). The authors refer to the category of memory as overcoming the destructive power of time, thinking about the fate of the people, its past, present and future. In the "My childhood" (1936) story by N. Tarabukin and in the novel "The Spirit of the earth" (1987) by P. Lamutskij autobiographical memory evolves into historical and cultural memory. The concept of "wild Tungus" goes far into the past, but the archetypal 
deep memory of the past becomes a symbol of revival. For example, in places of old encampments erected large houses, disappears "ilumu" - portable dwelling of the Evens in the form of a conical plague tungus type, along with the lost connection of generations.

Clenched the soul by black stone,

Pain and tears no longer concealing,

Moaning from injuries and wounds,

The land of mine is crying night and day.

("Land of ancestors" Krivoshapkin, 2016, p.32).

It is very interesting to embody the idea of the house and the homelessness in the Northern literature, which is implemented in the statement that the house for the Northern man is the land of his ancestors. As a rule, the image of the house in the world literature contains the archetypal semantics in the value of the private domestic space of the home, the fortress, the hearth, the giver of peace, security and protection. A nomad reindeer herder's house is the place where his deer grazes, and this movement is endless, instigated by an insatiable desire to see the area of the new camp as soon as possible, coupled with a constant struggle for survival. Therefore, in literary texts there is a predominance of autobiographical narrative, when the author himself is a carrier of nomadic culture and key mental images, a representative of the open dynamic space.

Even's abode is as follows,

what can a foreigner do not understand,

ilumu continues the nature,

or nature continues ilumu? Removable roof

unpretentious in wanderings, it is easy

and simply to live in, and clean, as in the forest.

And to be honest, the whole nature

is home to Even from an early age...

("Ilumu") (Krivoshapkin, 2016, p.36).

Considering the forms of representation of the "author's self", we found that the narrator in most works is presented as an autobiographical hero and lyrical hero, the subject of lyrical experiences and the subject of the narrative. For example, the trilogy "Life-long nomad" by A. Krivoshapkin was the creative experience of understanding his life path, in some way a "geographical journey" for the author himself. "My life is like a long, long nomad on unexplored trails on the steep slopes of the majestic mountains of the Verkhoyansk range. Today I'm all in the nomad. Only I do not know when to stop..." (Krivoshapkin, 2000, p.67).

In General, in our opinion, all the work of the author can be considered as a single autobiographical metatext. In the center of A. Krivoshapkin's creativity is the personality of the Northern man, his inner world, revealed in intense motion-journey, in real and imaginative spaces.

Genre features of the novel are built in accordance with the criteria of identity of the author - narrator hero, retrospective orientation and author's biography as a plot. At the same time, the image of local realities is based on explicit ethnographic regionalism, which includes relief, onomastics, toponymy and 
folklore. Descriptions of nature are associated with the idea of movement, with the philosophical understanding of the human way.

In this work we have identified the following characteristics of autobiographical narrative. First of all, it is status of the narrator, assuming identity of the narrator and the main character, as well as a retrospective narrative of his own existence with an emphasis on his individual life, especially on the history of his personality formation. Secondly, it is a type of language organization. We can observe the narrative reconstruction of the "Me" as a figure of speech. Autobiographical narrative in this case is not as much a chronicle of private life, genre or form, as it is a knowledge of himself, some creation of his own "Me". "Me-narrating" and "Me-character" in the body of the work are merged into the narrator role that performs function of self-presentation, self-knowledge. In this regard, the category of memory becomes an ontological and axiological value of life and creativity, a mean of life cognition. Memory appears as a universal tool for understanding yourself in the world and the world through the prism of your consciousness.

"...In my tundra childhood I caught the original views, when the herds seemed to have eclipsed the light with swaying abundance of horns, where the sun strove to sink, but floated to shine as soft gold on the reindeer horns. You will never forget that miracle: from generation to generation the child had admired it, feeling the connecting thread of centuries and days - community of deers and people" ("Sacred deer") (Krivoshapkin, 2008, p.4).

The construction of the text on the principle of retrospective-memories allows you to penetrate deeper into the psychology of the character, to find the most subtle strings of his soul in the arguments about his own life, the outside world, reflection, emotions and feelings. Space and time have a number of features which are characteristic to "memoir chronotope", when childhood, youth and maturity of the author are viewed through the prism of past years, the authenticity and reality of space and described events, combination of the hero's biographical time and historical time.

Thus, the description of the Northern territories and images in literary texts is more conceptual and psychological, expressed as a special attitude and as a special point of view of the world, the concept of the world. It can be traced that the concept of "Extreme North" becomes not a thematic phenomenon, but a mental value, a category of cultural thinking. It is the regional literature that most preserve national identity in both form and in value orientations.

\section{Conclusion}

Conceptualization of Northern text images is inextricably linked with the geographical and climatic features of the Arctic civilization in historical, geopoetic, anthropological, philosophical, aesthetic, cultural relation, and the dominant features of these images have a symbolic meaning. The importance of the "North" concept in the Northern literature of Yakutia is not only in the geographical, territorial boundaries, but to a greater extent in the symbolic meanings inherent in the historical and cultural memory of the people.

The main characteristic features of Northern space geopoetic images is the connection of opposite characteristics, equally defining it as natural, spatial, temporal. The perception of the North as a kind of socio-cultural system, specific way of life with its values associated with the traditional economic activities of the northerners, nomadic way of life, hunting, which in artistic interpretation are depicted primarily as a way of self-knowledge, inner state of the soul, the need for the soul, the naturalness of being and selfconsciousness. 
Thus, it can be concluded that the geopoetic image of the North is based not only on the interaction of author with the earth directly, but also with a place that was filled with identifying cultural signs, sacred meanings, semantically loaded before its development in the individual author's experience.

\section{References}

Chudnova, O.; Grudeva, E.; Chepurnaya, A.; Kizilova, N.; Makhova, I. \& Chvalun, R. (2018). Etymological Component of Concepts "Summer" and "Autumn" and Its Influence on National and Cultural Specifics in Perception of Seasons in Slavic and German Linguistic Cultures. Journal of History Culture and Art Research, 7(1), 364-372. DOI: http://dx.doi.org/10.7596/taksad.v7i1.1472

Galimova, E. Sh. (2014). The Northern text in the system of local (urban and regional) supertexts of Russian literature. Retrieved April 25, 2018 from http://narfu.ru/ifmk/cen_lab/ntext/files/galimova.pdf

Keptuke, G. (2009). Having his own name Djheltula river. Yakutsk: Bichik.

Keptuke, G. (2010). My dad is Santa Claus. Yakutsk: Bichik.

Krivoshapkin, A. N. (1990). Golden deer. Yakutsk: Book publishing house.

Krivoshapkin, A. N. (1995). Songs of the North: Poems. Yakutsk: Bichik.

Krivoshapkin, A. N. (2000). Life-long nomad. Yakutsk: Bichik.

Krivoshapkin, A. N. (2008). Sacred deer. Ethnographic poem. Yakutsk: Bichik.

Krivoshapkin, A. N. (2013). Reindeer people. Yakutsk: Bichik.

Krivoshapkin, A. N. (2014). Beneath the shadow of the North Star. Yakutsk: Bichik.

Krivoshapkin, A. N. (2015). My life, I would choose you again! Yakutsk: Bichik.

Krivoshapkin, A. N. (2016). "I am the son of the North". Moscow: publishing and printing Association "At Nikitsky gate".

Kurilov, G. N. (2013). Selected works: poems, stories, essays, publicism. Yakutsk: Bichik.

Lamutskij, P. (1987). The spirit of the earth: translated from Even language by P. Avvakumov. Yakutsk: Bichik.

Lotman, Ju. M. (1992). Articles on semiotics and typology of culture. Tallinn: "Alexandra".

Odulok, T. (1959). On The Far North. Yakutsk: Bichik.

Popkov, D. V. \& Tyugashev, E. A. (2006). Philosophy of the North: Indigenous Peoples of the North in the scenarios of the world's order. Novosibirsk: Siberian scientific publishing house. 
Tarabukin, N. S. (1936). My childhood. Leningrad: Detizdat.

Toporov, V. N. (1983). Space and text. Text: semantics and structure. Moscow: Science.

Toporov, V. N. (2003). Petersburg text of Russian literature. St. Petersburg: Art. 